\title{
Pengembangan Modul MIPO (Menemukan Ide Pokok) Berbasis Model Pembelajaran CIRC pada Cerita Nonfiksi di Kelas V Sekolah Dasar
}

\author{
Universitas Sultan Ageng Tirtayasa \\ windi8indriyani@gmail.com
}

Windi Indriyani, Rina Yuliana, Istinganatul Ngulwiyah

\section{Article History}

received 10/5/2021

\begin{abstract}
This development research is based on elementary school age students who still have difficulty finding the main idea of paragraphs because the teaching materials and learning models applied are not appropriate for learning to find paragraph main ideas, so it is necessary to develop a MIPO module based on the CIRC learning model. This study aims to develop a MIPO module based on the CIRC learning model in nonfiction stories. The research method used is research and development $(R \& D)$ in the form of quantitative and qualitative. Quantitative data were obtained based on expert test results and student responses. Meanwhile, the qualitative data is based on the results of observations, interviews, and comments from the media, language, and material expert validators. The results of the research resulted in a product in the form of the MIPO Module CIRC Learning Based Model for Class V Elementary School Students which can make it easier for students to find paragraph main ideas and understand the material /information of a nonfiction story text they read. In addition, it can be concluded that the product developed can foster an attitude of independence and cooperation among students in learning activities.
\end{abstract}

Keywords: MIPO Module, CIRC Model, Non-fiction, Class V Elementary School.

\section{Abstrak}

Penelitian pengembangan ini berdasarkan pada peserta didik usia sekolah dasar yang masih mengalami kesulitan dalam menemukan ide pokok paragraf karena bahan ajar dan model pembelajaran yang diterapkan kurang tepat untuk pembelajaran menemukan ide pokok paragraf, sehingga perlu dikembangkan sebuah modul MIPO berbasis model pembelajaran CIRC. Penelitian ini bertujuan untuk mengembangkan modul MIPO (Menemukan Ide Pokok) berbasis model pembelajaran CIRC pada cerita nonfiksi. Metode penelitian yang digunakan yaitu penelitian pengembangan (R\&D) berbentuk kuantitatif dan kualitatif. Data kuantitafif diperoleh berdasarkan hasil uji ahli dan respons peserta didik. Sementara data kualitatif berdasarkan hasil observasi, wawancara, dan komentar dari validator ahli media, bahasa, serta materi. Hasil penelitian menghasilkan produk berupa Modul MIPO (Menemukan Ide Pokok) Model Berbasis Pembelajaran CIRC untuk Siswa Kelas V Sekolah Dasar yang dapat memudahkan peserta didik dalam menemukan ide pokok paragraf dan memahami materi / informasi sebuah teks cerita nonfiksi yang dibacanya. Selain itu, dapat disimpulkan bahwa produk yang dikembangkan dapat menumbuhkan sikap kemandirian dan kerja sama antar peserta didik dalam kegiatan pembelajaran.

Kata Kunci: Modul MIPO, Model Pembelajaran CIRC, Nonfiksi, Kelas V Sekolah Dasar. 


\section{PENDAHULUAN}

Pembelajaran pada hakikatnya ialah suatu proses komunikasi antara pendidik, peserta didik dan sumber belajar untuk menyampaikan ilmu pengetahuan. Dalam kurikulum 2013, pembelajaran tidak lagi dilakukan secara terpisah dengan berbagai macam bidang studi, melainkan dilakukan secara terpadu dalam pembelajaran tematik. Menurut Depdiknas (Akbar et al., 2016), bahwa pembelajaran tematik merupakan pembelajaran terpadu yang mengaitkan beberapa mata pelajaran ke dalam suatu tema sehingga menciptakan pembelajaran yang bermakna. Beberapa mata pelajaran yang diintegrasikan dalam pembelajaran tematik terpadu yaitu Bahasa Indonesia, Matematika, IPA, IPS, PJOK, dan SBdP.

Muatan pembelajaran Bahasa Indonesia yang terintegrasi dalam pembelajaran tematik dijadikan sebagai dasar ilmu pengetahuan untuk mempelajari mata pelajaran lainnya. Hal ini sesuai dengan (Mahsun, 2014), bahwa pembelajaran Bahasa Indonesia adalah penghela ilmu pengetahuan. Bahasa Indonesia merupakan prioritas utama dalam memperoleh pengetahuan karena melalui penguasaan Bahasa Indonesia, peserta didik dapat mempelajari pengetahuan lain dengan menyerap, mengembangkan, serta mengkomunikasikannya. Selain itu, pembelajaran Bahasa Indonesia juga dijadikan sebagai sarana mendistribusikan kompetensi dasar, mengalihkan satu materi ke materi yang lain dalam substansi mata pelajaran yang berbeda yang terintegrasi dalam pembelajaran tematik terpadu. (Kurniawan, 2015), mengatakan hal yang sama bahwa materi dalam pembelajaran Bahasa Indonesia sudah disesuaikan dengan tema yang harus dibelajarkan kepada peserta didik sehingga tercapainya tujuan pembelajaran sesuai dengan $\mathrm{KI}$, KD dan indikator pembelajaran.

Salah satu Kompetensi dasar kelas $\mathrm{V}$ sekolah dasar yakni menguraikan konsepkonsep yang saling berkaitan pada teks nonfiksi. Kompetensi dasar tersebut dikembangkan ke dalam indikator pembelajaran mengidentifikasi ide pokok paragraf cerita nonfiksi yang merupakan salah satu indikator penting dalam pembelajaran di sekolah dasar. Peserta didik yang mampu mengidentifikasi, menemukan, dan menuliskan ide pokok paragraf akan mampu memahami informasi yang disampaikan pada teks yang dibaca dan mampu mengembangkan keterampilan berbahasanya. Namun tidak sedikit peserta didik yang kesulitan dalam menemukan ide pokok paragraf pada cerita nonfiksi maupun fiski. Hal tersebut terjadi karena materi ide pokok yang terintegrasi dalam pembelajaran tematik sudah dipadukan dengan mata pelajaran lainnya dengan cakupan materi yang cukup luas dan tidak terfokusnya suatu materi pada satu bidang studi mengakibatkan peserta didik kesulitan memahami materi pembelajaran.

Berdasarkan pengamatan peneliti di masa pandemi Covid 19, ketika membantu kegiatan belajar peserta didik sekolah dasar, peneliti menemukan bahwa masih banyak peserta didik yang belum memahami bagaimana cara menentukan ide pokok paragraf dengan benar. Hal yang serupa juga berdasarkan wawancara yang telah dilakukan dengan wali kelas VB SDN Sempu diperoleh informasi bahwa salah satu permasalahan dalam pembelajaran adalah peserta didik belum memahami bagaimana menemukan ide pokok paragraf. Hal ini disebabkan karena belum adanya bahan ajar pendukung dan belum diterapkannya pembelajaran kelompok dalam pembelajaran menemukan ide pokok paragraf. Kegiatan pembelajaran masih sering dilakukan secara individual dan menggunakan model konvensional.

Peran pendidik sangat penting dalam mengatasi masalah tersebut, baik dalam segi penyampaian materi maupun mengembangkan komponen pembelajaran. Pendidik harus mampu mengembangkan kegiatan pembelajaran yang menarik, menyenangkan, bermakna, serta mudah dipahami peserta didik. Salah satu peran pendidik ialah harus mampu mengembangkan bahan ajar yang disesuaikan dengan kurikulum, karakteristik, serta kebutuhan peserta didik. Sependapat dengan 
pernyataan (Jamaludin \& Rachmatullah, 2017) bahwa pendidik sebagai tenaga profesional dituntut untuk tetap mengembangkan bahan ajar sekalipun sudah tersedia bahan ajar yang sesuai dengan kurikulum. Bahan ajar yang dikembangkan dapat berupa bahan ajar pokok (buku teks, modul, dan buku panduan utama lainnya) dan pendukung (buku bacaan, majalah, video, komik, dan lainnya)

Salah satu sarana untuk mempelajari materi dalam menemukan ide pokok paragraf cerita nonfiksi di sekolah dasar dengan mengembangkan bahan ajar berupa modul MIPO (Menemukan Ide Pokok) berbasis model CIRC. Modul ini mengintegrasikan lima muatan pelajaran yang dikemas dalam bentuk cerita nonfiksi serta model CIRC yang menjadi ciri khas pengembangannya khususnya pada bagian kegiatan peserta didik. Hal ini sesuai dengan (Muhammad Wahyu Setiyadi, Ismail, 2017) yang mengemukakan bahwa salah satu cara untuk meningkatkan pemahaman ataupun hasil belajar peserta didik yaitu dengan mengembangkan bahan ajar yang baik. Berdasarkan penelitian terdahulu yang dilakukan oleh (Azizah, 2019) terkait pengembangan bahan ajar menggunakan model pembelajaran CIRC juga membuktikan bahwa pengembangan tersebut mampu meningkatkan pemahaman dan hasil belajar peserta didik.

Modul MIPO dirancang dengan tujuan peserta didik mampu belajar secara mandiri baik dengan atau tanpa adanya bimbingan pendidik yang di dalamnya memuat petunjuk belajar, KD, materi ide pokok paragraf dilengkapi cara dan contoh cerita nonfiksi, latihan, evaluasi, serta hasil evaluasi yang disajikan menggunakan bahasa yang mudah dimengerti. Hal ini sesuai dengan pendapat (Daryanto, 2013) dan (Najuah et al., 2020), bahwa modul pembelajaran digunakan peserta didik kepada dirinya sendiri (self-instructional) yang memuat unsur/komponen modul pada umumnya. Sementara model CIRC merupakan salah satu model pembelajaran kelompok yang mengintegrasikan keterampilan berbahasa, khususnya keterampilan membaca dan menulis yang cukup sesuai dalam pembelajaran menemukan ide pokok paragraf. Sependapat dengan (Slavin, 2014), bahwa model CIRC adalah model pembelajaran yang relevan untuk pembelajaran membaca, menulis, dan seni berbahasa. (Niliawati et al., 2018) mengatakan hal yang sama bahwa CIRC adalah sebuah metode pembelajaran terintegrasi membaca dan menulis yang melibatkan peserta didik secara aktif sehingga dapat memudahkan peserta didik memahami isi bacaan yang baca. Sedangkan (Zainuddin, 2015) dan (Puspitasari \& Hidayat, n.d.) mengatakan bahwa CIRC adalah suatu teknik pengajaran keterampilan bahasa yang relevan bagi peserta didik kelas tinggi.

Upaya tersebut dilakukan agar peserta didik mampu menemukan ide pokok paragraf sehingga dapat mengetahui informasi yang disampaikan pada cerita nonfiksi secara benar dan menyeluruh. Selain itu, pengembangan modul tersebut dapat mengembangkan keterampilan berbahasa, menjadikan kegiatan pembelajaran lebih aktif dan bermakna karena dilengkapi dengan beberapa gambar yang menarik.

Berdasarkan hal tersebut, rumusan masalah dalam penelitian pengembangan ini ialah bagaimana proses pengembangan, tingkaat kelayakan, serta respons peserta didik terhadap pengembangan modul MIPO berbasis model CIRC. Sementara yang menjadi tujuan penelitian ini ialah untuk mendeskripsikan proses pengembangan, kelayakan, serta respons peserta didik terhadap pengembangan modul MIPO berbasis model CIRC. 


\section{METODE}

Penelitian dilakukan di SDN Sempu dengan subjek penelitian yaitu 15 peserta didik berdasarkan teknik sistematis sampling. Metode penelitian yang digunakan yaitu metode R\&D suatu metode penelitian untuk mengembangkan produk yang sudah ada sebelumnya/produk baru tertentu untuk memperbaiki proses dan hasil pembelajaran. Sejalan dengan (Sugiyono, 2013) bahwa penelitian pengembangan digunakan untuk menciptakan suatu produk dan menguji keefektifannya. Langkah penelitian pengembangan ini berdasarkan pada enam langkah menurut Borg and Gall meliputi analisis masalah, pengumpulan data, desain produk, validasi produk, revisi produk, dan uji coba produk.

Teknik pengumpulan data penelitian yang digunakan yaitu observasi tidak terstruktur, wawancara tidak terstruktur, angket, dan dokumentasi. Observasi dan wawancara tidak terstruktur untuk mengetahui permasalahan dalam pembelajaran menemukan ide pokok. Serta mengetahui kebutuhan terhadap produk yang peneliti kembangkan. Angket penelitian pengembangan ini berupa angket validasi ahli untuk mengetahui tingkat kelayakan produk yang peneliti kembangkan dari segi desain, bahasa, dan materi serta angket respons untuk mengetahui respons peserta didik setelah menggunakan produk yang peneliti kembangkan. Sementara dokumentasi dijadikan bukti bahwa penelitian pengembangan ini sesungguhnya dilakukan. Teknik analisis dan keabsahan data penelitian pengembangan ini berdasarkan pada analisis skala Likert skor 1-5 untuk menghitung analisis kelayakan dari tim ahli dan skala Guttman skor 1 dan 0 untuk menghitung respons peserta didik.

\section{HASIL DAN PEMBAHASAN}

Penelitian ini dilakukan di SD Negeri Sempu yang terletak di Kp. Teluk Bako, Ds. Mangkunegara, Kec. Bojonegara, Kab. Serang, Prov. Banten. Proses pelaksanaan penelitian ini dilakukan berdasarkan pada 6 tahapan menurut Borg and Gell. Berdasarkan 6 tahapan yang telah dilakukan maka diperoleh hasil penelitian sebagai berikut:

1. Hasil Validasi Ahli/Kelayakan Produk

Tahap validasi ahli bertujuan mendeskripsikan kelayakan produk yang dikembangkan peneliti berdasarkan penilaian tim ahli meliputi validasi ahli desain, bahasa, dan materi.

Tabel 1. Data Penilaian Ahli Media

\begin{tabular}{|c|c|c|c|c|}
\hline \multirow{2}{*}{$\begin{array}{c}\text { Uji } \\
\text { Ahli }\end{array}$} & \multirow[t]{2}{*}{ Aspek } & \multicolumn{2}{|c|}{ Skor } & \multirow[t]{2}{*}{ Np (\%) total } \\
\hline & & Ahli Media 1 & Ahli Media 2 & \\
\hline \multirow{5}{*}{$\begin{array}{c}\text { Ahli } \\
\text { Media }\end{array}$} & Format & \multirow[t]{5}{*}{71} & \multirow[t]{5}{*}{78} & \multirow[t]{5}{*}{149} \\
\hline & Organisasi & & & \\
\hline & Daya Tarik & & & \\
\hline & $\begin{array}{c}\text { Jenis dan } \\
\text { ukuran } \\
\text { Huruf }\end{array}$ & & & \\
\hline & Spasi & & & \\
\hline \multicolumn{2}{|c|}{ Jumlah } & $\frac{71}{85} \times 100=83 \%$ & $\frac{78}{85} \times 100=91 \%$ & $\frac{149}{170} \times 100=87 \%$ \\
\hline \multicolumn{2}{|c|}{ Rata-Rata } & \multicolumn{3}{|c|}{$\frac{+91}{2} \times 100=87 \%$} \\
\hline \multicolumn{2}{|c|}{ Kriteria Kelayakan } & \multicolumn{3}{|c|}{ Sangat Layak } \\
\hline
\end{tabular}

Berdasarkan data penilaian ahli media di atas menunjukkan bahwa diperoleh penilaian dari ahli media 1 sebesar $83 \%$ dan ahli media 2 sebesar $92 \%$ sehingga 
diperoleh rata-rata sebesar $87 \%$ masuk dalam kategori "Sangat Layak" menurut (Purwanto, 2013).

Tabel 2. Data Penilaian Ahli Bahasa

\begin{tabular}{|c|c|c|c|c|}
\hline \multirow{2}{*}{$\begin{array}{l}\text { Uji } \\
\text { Ahli }\end{array}$} & \multirow[t]{2}{*}{ Aspek } & \multicolumn{2}{|c|}{ Skor } & \multirow[t]{2}{*}{ Np (\%) total } \\
\hline & & Ahli Bahasa 1 & Ahli Bahasa 2 & \\
\hline \multirow[t]{3}{*}{$\begin{array}{c}\text { Ahli } \\
\text { Media }\end{array}$} & $\begin{array}{c}\text { Gaya } \\
\text { Bahasa }\end{array}$ & \multirow[t]{3}{*}{43} & \multirow[t]{3}{*}{41} & \multirow[t]{3}{*}{84} \\
\hline & Tata Bahasa & & & \\
\hline & $\begin{array}{l}\text { Penyusunan } \\
\text { Paragraf }\end{array}$ & & & \\
\hline \multicolumn{2}{|r|}{ Jumlah } & $\frac{43}{45} \times 100=95 \%$ & $\frac{41}{45} \times 100=91 \%$ & $\frac{84}{90} \times 100=93 \%$ \\
\hline \multicolumn{2}{|c|}{ Rata-Rata } & \multicolumn{3}{|c|}{$\frac{95+91}{2} \times 100=93 \%$} \\
\hline \multicolumn{2}{|c|}{ Kriteria Kelayakan } & \multicolumn{3}{|c|}{ Sangat layak } \\
\hline
\end{tabular}

Berdasarkan data penilaian ahli bahasa di atas diperoleh penilaian dari ahli bahasa 1 sebesar 95\% dan ahli bahasa 2 sebesar 91\% sehingga diperoleh nilai rata-rata sebesar 93\%. Dengan demikian modul MIPO berbasis model pembelajaran CIRC dari segi bahasa termasuk ke dalam kategori "Sangat Layak" menurut (Purwanto, 2013).

Tabel 3. Data Penilaian Ahli Materi

\begin{tabular}{|c|c|c|c|c|}
\hline \multirow{2}{*}{$\begin{array}{c}\text { Uji } \\
\text { Ahli }\end{array}$} & \multirow{2}{*}{ Aspek } & \multicolumn{2}{|c|}{ Sp (\%) total } \\
\cline { 3 - 4 } $\begin{array}{c}\text { Ahli } \\
\text { Materi }\end{array}$ & $\begin{array}{c}\text { Relevansi } \\
\text { Materi }\end{array}$ & 53 & Ahli Media 2 & \\
\cline { 2 - 4 } & $\begin{array}{c}\text { Sajian } \\
\text { Materi }\end{array}$ & & 58 & \\
\hline \multicolumn{2}{|c|}{ Jumlah } & $\frac{53}{60} \times 111$ & \\
\hline \multicolumn{2}{|c|}{ Rata-Rata } & \multicolumn{3}{|c|}{$\frac{88+96}{2} \times 100=92 \%$} \\
\hline Kriteria Kelayakan & \multicolumn{3}{|c|}{ Sangat Layak } \\
\hline
\end{tabular}

Berdasarkan data penilaian ahli materi di atas diperoleh hasil penilaian dari ahli materi 1 sebesar $88 \%$ dan ahli materi 2 sebesar 96\% sehingga diperoleh rata-rata sebesar 92\%. Dengan demikian modul MIPO berbasis model pembelajaran CIRC dari segi materi termasuk ke dalam kategori “Sangat Layak” menurut (Purwanto, 2013).

2. Hasil Angket Respons Peserta Didik

Angket ini untuk mengetahui dan mendeskripsikan respons peserta didik terhadap produk yang peneliti kembangkan. Responden pada penelitian ini berjumlah 15 peserta didik kelas VB SDN Sempu Berikut data hasil angket respons peserta didik. 
Tabel 4. Data Penilaian Respons Peserta Didik

\begin{tabular}{|c|c|c|c|}
\hline No & Skor & Persentase & Keterangan \\
\hline R1 & 7 & $70 \%$ & Baik \\
\hline R2 & 8 & $80 \%$ & Baik \\
\hline R3 & 9 & $90 \%$ & Sangat Baik \\
\hline R4 & 9 & $90 \%$ & Sangat Baik \\
\hline R5 & 10 & $100 \%$ & Sangat Baik \\
\hline R6 & 9 & $90 \%$ & Sangat Baik \\
\hline R7 & 10 & $100 \%$ & Sangat Baik \\
\hline R8 & 10 & $100 \%$ & Sangat Baik \\
\hline R9 & 10 & $100 \%$ & Sangat Baik \\
\hline R10 & 10 & $100 \%$ & Sangat Baik \\
\hline R11 & 9 & $100 \%$ & Sangat Baik \\
\hline R12 & 10 & $100 \%$ & Sangat Baik \\
\hline R13 & 8 & $80 \%$ & Baik \\
\hline R14 & 9 & $90 \%$ & Sangat Baik \\
\hline R15 & 9 & $90 \%$ & Sangat Baik \\
\hline NA & 137 & $91 \%$ & Sangat Baik \\
\hline
\end{tabular}

Berdasarkan diagram angket respons peserta didik di atas, diperoleh rata-rata sebesar 91\% dengan kategori "Sangat Baik" berdasarkan tabel interpretasi menurut (Riduwan, 2013). Dengan demikian, modul MIPO berbasis model CIRC mendapatkan respons yang sangat positif dari peserta didik.

Produk akhir penelitian dan pengembangan ini yaitu modul pembelajaran untuk menemukan ide pokok paragraf sebuah teks nonfiksi dengan judul "Modul MIPO (Menemukan Ide Pokok) Tema 3 Ekosistem Subtema 3 Keseimbangan Ekosistem untuk Siswa Kelas V Sekolah Dasar". Modul MIPO di dalamnya mengintegrasikan muatan pelajaran yaitu Bahasa Indonesia, IPA, IPS, PPKn, dan SBdP yang dikemas dalam sebuah cerita nonfiksi yang terdapat pada modul sehingga peserta didik tidak hanya mampu mengetahui bagaimana cara menemukan ide pokok paragraf sebuah cerita melainkan mampu mengetahui informasi yang terkandung pada sebuah cerita tersebut. Dalam penerapan pembelajarannya modul ini berdasarkan pada sintaks model pembelajaran CIRC.
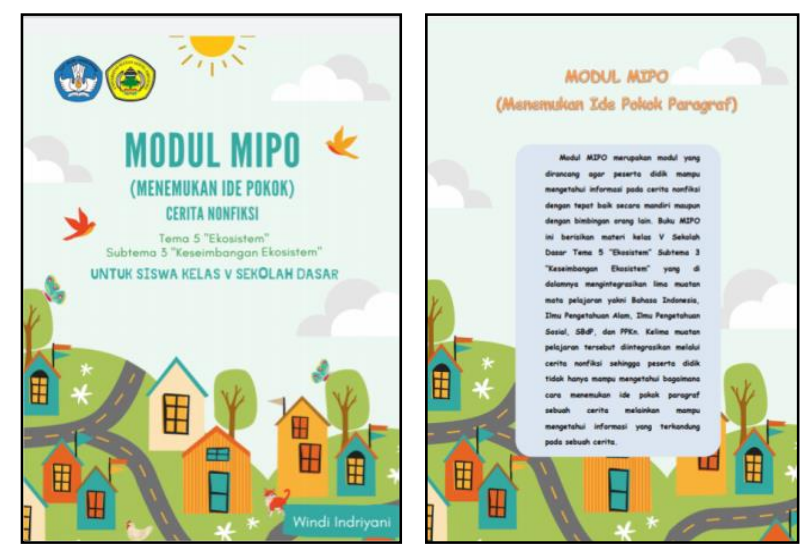

Gambar 1.Produk Akhir Modul MIPO Berbasis Model Pembelajaran CIRC 
Pada saat melakukan uji coba menggunakan modul MIPO berbasis CIRC, peneliti menemukan temuan penelitian saat pelaksanaan pembelajaran menggunakan produk yang peneliti kembangkan. Peserta didik secara berkelompok mampu bekerja sama dengan baik dalam kelompok. Peserta didik saling berdiskusi, mengutarakan pendapat, serta saling membantu untuk bersama-sama menemukan ide pokok paragraf dengan tepat. Selain itu, dengan menggunakan modul MIPO berbasis model CIRC ini dapat meningkatkan antusias peserta didik untuk mempelajarinya serta meningkatkan hasil belajar dimana pada saat uji coba produk, peserta didik mampu mengerjakan soal kelompok bersama kelompoknya dengan benar. Hal ini sesuai dengan pendapat (Slavin, 2014) bahwa kelebihan model CIRC dalam pembelajaran yakni a) meningkatkan pemahaman terhadap topik yang dipelajari, b) pembelajaran bersifat student center, c) memotivasi untuk bekerja sama dan saling membantu dalam kelompok, d) saling memahami makna soal dan memeriksa tugas, f) meningkatkan hasil belajar, g) memberikan kebebasan berpendapat dan saling menghormati pendapat orang lain.

Penelitian yang pernah dilakukan (Sirate \& Ramadhana, 2017), (Nurzayyana et al., 2020) dan (Puspitasari \& Hidayat, n.d.) mengatakan bahwa modul yang dikembangkan dapat membuat peserta didik aktif dalam kegiatan pembelajaran, menumbuhkan motivasi, memperoleh hasil belajar yang sesuai dengan kemampuannya, dan menghargai perbedaan individu. Penelitian yang pernah dilakukan (Awatik, 2019) menunjukkan pengaruh positif dari penerapan model CIRC dalam pembelajaran menemukan ide pokok karena dengan berkelompok, peserta didik dapat berinteraksi, bertukar ide, dan bekerja sama menyelesaikan tugas yang berikan pendidik sehingga dapat mengembangkan kemampuan sosial dan menjadi lebih termotivasi untuk mengikuti kegiatan pembelajaran. (Handayani, 2018) juga mengatakan bahwa adanya perbedaan antara peserta didik yang menggunakan dan tidak menggunakan model CIRC dalam pembelajaran dimana peserta didik yang menggunakan memperoleh prestasi yang lebih unggul dibandingkan dengan peserta didik yang menggunakan model klasikal.

Kekurangan yang peneliti temukan saat uji coba produk yaitu kegiatan pembelajaran didominasi oleh peserta didik yang memiliki kemampuan lebih sehingga membuat beberapa peserta didik yang berkemampuan kurang lebih banyak diam. Hal ini serupa dengan pendapat (Slavin, 2014) bahwa peserta didik yang aktif yang mendominasi kegiatan pembelajaran. (Huda, 2014), juga mengatakan bahwa peserta didik mudah kehilangan kemampuan karena didominasi oleh peserta didik yang mampu serta dalam diskusi terkadang hanya dikerjakan oleh beberapa peserta didik saja (Kintan \& Lubis, 2016).

\section{SIMPULAN}

Berdasarkan hasil penelitian dan pengembangan yang dilakukan didapatkan kesimpulan sebagai berikut:

1. Produk akhir yang dikembangkan berupa modul MIPO berbasis model pembelajaran CIRC dapat membantu peserta didik untuk menemukan ide pokok paragraf, memahami isi cerita, menjadikan kegiatan pembelajaran lebih bermakna.

2. Kelayakan modul MIPO (Menemukan Ide Pokok) berbasis model pembelajaran CIRC diperoleh penilaian dengan persentase $87 \%$ dari dua ahli media, $93 \%$ dari dua ahli bahasa, dan $92 \%$ dari dua ahli materi sehingga diperoleh rata-rata sebesar 90\% dengan kategori "Sangat Layak".

3. Respons peserta didik terhadap modul MIPO (Menemukan Ide Pokok) berbasis model pembelajaran CIRC uji coba lapangan yang melibatkan 15 peserta didik memperoleh persentase $91 \%$ termasuk dalam kategori "Sangat Baik". 
Pengembangan modul MIPO berbasis model pembelajaran CIRC ini diharapkan dapat digunakan pendidik sebagai referensidan bahan ajar pendukung dalam pembelajaran menemukan ide pokok serta dapat digunakan peserta didik untuk belajar secara mandiri/kelompok dalam menemukan ide pokok dengan mudah.

\section{DAFTAR PUSTAKA}

Akbar, S., A'yun, I. Q., Satriyani, F. Y., Widodo, W., S.K, R. P., \& Ferisa, D. (2016). Implementasi Pembelajaran Tematik di Sekolah Dasar. Remaja Rosdakarya.

Awatik. (2019). Pembelajaran dengan Cooperative Integrated Reading and Composition (CIRC) dalam Meningkatkan Kemampuan Menemukan Pokok Pikiran. Jurnal Pendidikan Dasar, 1(2), 56-63.

Azizah, L. N. (2019). Pengembangan Buku Suplemen Bahasa Indonesia Berbasis Budaya Lokal Menggunakan Model pembelajaran CIRC untuk Siswa Sekolah Dasar. Jurnal Pendidikan Anak Dan Karakter, 1(2), 1-7.

Daryanto. (2013). Menyusun Modul Bahan Ajar untuk Persiapan Guru dalam Mengajar. Gava Media.

Handayani, M. (2018). Jurnal Prima Edukasia , 6 ( 2 ), 2018 , 166-176 Developing Thematic-Integrative Learning Module with Problem-Based Learning Model for Elementary School Students. 6(2), 166-176.

Huda, M. (2014). Model-Model Pengajaran dan Pembelajaran:Isu-Isu Metodis dan Paragmatis. Pustaka Belajar.

Jamaludin, U., \& Rachmatullah, R. (2017). Pembelajaran Pendidikan IPS Teori Konsep dan Aplikasi bagi Guru dan Mahasiswa. Penerbit Nurani.

Kintan, J., \& Lubis, A. (2016). Penerapan Model Pembelajaran Cooperative Integrated Reading And Composition (CIRC) untuk Meningkatkan Motivasi dan Hasil Belajar Konstruksi Bangunan Siswa Kelas X TGB SMK Negeri 1 Lubuk Pakam. Jurnal Education Building, 2(1), 77-86.

Kurniawan, H. (2015). Pembelajaran Kreatif Bahasa Indonesia Kurikulum 2013. Prenadamedia Group.

Mahsun, M. . (2014). Teks dalam Pembelajaran Bahasa Indonesia (Kurikulum 2013). PT Raja Grafindo Persada.

Muhammad Wahyu Setiyadi, Ismail, H. A. G. (2017). Pengembangan Modul Pembelajaran Biologi Berbasis Pendekatan Saintifik Untuk Meningkatkan Hasil Belajar Siswa. Journal of Educational Science and Technology (EST), 3(2), 104.

Najuah, Lukitoyo, P. S., \& Wirianti, W. (2020). Modul Elektronik: Prosedur Penyusunan dan Aplikasinya. Yayasan Kita Menulis.

Niliawati, L., Hermawan, R., \& Riyadi, A. R. (2018). Penerapan Metode CIRC (Cooperative Integrated Reading And Composition) untuk Meningkatkan Kemampuan Membaca Pemahaman Siswa Kelas IV. Jurnal Pendidikan Guru Sekolah Dasar, 3(1), 23-30.

Nurzayyana, A., Danyati, I. P., \& Akmalia, Z. (2020). Jurnal PAJAR (Pendidikan dan Pengajaran ) Volume 4 Nomor 4 Juli 2020 | ISSN Cetak: 2580 - 8435 / ISSN Online: 2614 - 1337 DOI: http://dx.doi.org/10.33578/pjr.v4i2.8012 THE EFFECT OF COOPERATIVE INTEGRATED READING AND COMPOSITION ( CIRC ) LEARNING MODEL TO IMPROVE LEARNING OUTCOME OF INDONESIAN LANGUAGE IN DETERMINING SENTENCE OF ADVICE FOR GRADE 3 STUDENTS AT SD NEGERI 148 PEKANBARU PENGARUH MODEL PEMBELAJARAN COOPERATIVE INTEGRATED READING AND COMPOSITION ( CIRC ) UNTUK MENINGKATKAN HASIL BELAJAR BAHASA INDONESIA DALAM MENENTUKAN KALIMAT SARAN SISWA KELAS III SD Jurnal PAJAR ( Pendidikan dan Pengajaran ) Volume 4 Nomor 4 Juli 2020 / ISSN Cetak : 2580 - 8435 | ISSN Online : 2614 - 1337. 4, 671-679.

Purwanto, N. (2013). Prinsip-Prinsip dan Teknik Evaluasi Pengajaran. PT Remaja 
Rosdakarya.

Puspitasari, C. A., \& Hidayat, D. (n.d.). THE IMPLEMENTATION OF THE COOPERATIVE INTEGRATED READING AND COMPOSITION TECHNIQUE TO INCREASE GRADE 8 STUDENTS ' ACTIVE LEARNING IN AN ENGLISH CLASS. 223-238.

Riduwan. (2013). Dasar-dasar Statistika. Bandung: Alfabeta.

Sirate, S. F. S., \& Ramadhana, R. (2017). Pengembangan Modul Pembelajaran Berbasis Keterampilan Literasi. Jurnal Auladuna2, 6(2), 316-335.

Slavin, R. . (2014). Cooperative Learning (Teori, Riset dan Praktik). Nuasamedia.

Sugiyono. (2013). Metode Penelitian Kuantitatif, Kualitatif dan R\&D. Alfabeta.

Zainuddin. (2015). The effect of cooperative integrated reading and composition technique on students' reading descriptive text achievement. English Language Teaching, 8(5), 11-21. https://doi.org/10.5539/elt.v8n5p11 